Desimal: Jurnal Matematika,1(2), 2018, 229 - 235

\title{
Prestasi dan Kemandirian Belajar dalam Geometri Tranformasi melalui Learning Cycle 5E Berbantuan Software
}

\author{
Pitriani \\ Universitas Tamansiswa Palembang. Jalan Taman Siswa No. 261, Palembang 30126, Indonesia. \\ *Corresponding Author. Email: pitriani@unitaspalembang.ac.id
}

Received : 27-04-2018; Revised : 13-05-2018; Accepted : 31-05-2018

\begin{abstract}
Abstrak
Penelitian tindakan kelas ini bertujuan untuk mendeskripsikan prestasi belajar dan kemandirian belajar mahasiswa setelah mengikuti pembelajaran dengan Learning Cycle 5E (LC 5E) berbantuan software. Tahapan dalam LC 5E adalah engagement, exploration, explanation, elaboration, dan evaluation. Adapun software yang digunakan dalam penelitian ini adalah GeoGebra. Subjek penelitian adalah 15 mahasiswa Program Studi Pendidikan Matematika FKIP Universitas Tamansiswa Palembang Tahun Akademik 2017/2018 Semester Ganjil yang mengambil Mata Kuliah Geometri Transformasi. Penelitian tindakan kelas dengan dua siklus ini meliputi langkah-langkah perencanaan, implementasi tindakan, observasi, dan refleksi. Kondisi awal (pra-siklus) menunjukkan bahwa rata-rata prestasi mahasiswa adalah 55.64 dengan ratarata ketuntasan belajar 54.29\%. Setelah dilaksanakan pembelajaran LC 5E berbantuan software rata-rata prestasi mahasiswa meningkat menjadi 58,56 (60,00\%) pada siklus I dan 81.44 $(86,67 \%)$ pada siklus II. Kemandirian belajar mahasiswa menunjukkan hasil yang positif. Mahasiswa memperlihatkan tanggapan positif terhadap pembelajaran. Mahasiswa juga antusias dan termotivasi mengikuti pembelajaran. Mahasiswa mampu menentukan strategi belajar yang tepat sehingga berefek positif pada prestasi belajar mahasiswa.
\end{abstract}

Kata kunci: Learning Cycle 5E, prestasi, kemandirian belajar

\begin{abstract}
This action research was aimed at describing the students' achievement and self-regulated learning after taking the instruction using Software-Assisted Learning Cycle 5E. Learning Cycle $5 E$ are engagement, exploration, explanation, elaboration, and evaluation. The subjects were the students of the Mathematics Education Department of FKIP Universitas Tamansiswa Palembang taking Geometry Transformation Subject in the 2017/2018. The steps of this two-cycle action research included: planning, acting, observing, and reflecting. The prior condition (pre-cycle) showed that the average of students' achievement is 55.64 with the average student passing is 54,29\%. After the application of Reciprocal Teaching, the average of students'achievement increased to 58,56 in cycle I (60,00\%) and to 81,44 (86,67\%) in cycle II. Self-regulated learning shows the positive result. The students showed a positive response. The students were enthusiastic about joining the class.
\end{abstract}

Keywords: Learning Cycle 5E, students' achievement, self regulated learning 


\section{PENDAHULUAN}

Geometri Transformasi merupakan bagian dari geometri yang khusus membicarakan perubahan, baik perubahan letak maupun bentuk penyajianya didasarkan dengan gambar dan matriks. Setidaknya ada empat yang dibahas dalam mata kuliah ini, yaitu: translasi, refleksi, rotasi, dan dilatasi. Materi-materi tersebut adalah bukan hal yang baru bagi mahasiswa karena telah dibahas di bangku SMA.

Meskipun demikian, prestasi dan kemandirian belajar mahasiswa yang belum tercapai dengan baik. Mahasiswa masih mengalami kesulitan belajar. Mahasiswa cenderung pasif karena terbiasa belajar dengan metode ceramah, hanya menerima apa yang diinformasikan oleh dosennya. Dengan kata lain, kemandirian belajar mahasiswa belum optimal. Hal ini berdampak pada prestasi belajar yang relatif masih rendah.

Peneliti berpendapat bahwa perlu melakukan riset untuk mengatasi hal tersebut, yaitu menerapkan pembelajaran yang lebih inovatif. Pembelajaran yang inovatif untuk mengatasi permasalahan tersebut adalah pembelajaran yang mampu memfasilitasi mahasiswa membangun pemahamannya sendiri dengan memanfaatkan kecanggihan teknologi.

Lorsbach (2002) memaparkan bahwa Learning Cycle 5E (LC 5E) merupakan salah satu model pembelajaran konstruktivisme yang dalam proses pembelajarannya membekali penggunanya (baik siswa maupun mahasiswa) dengan konsep atau pemahaman baru secara mendalam. Selain itu, LC 5E memasukkan keterampilan berpikir tingkat tinggi, merangsang untuk melakukan eksplorasi, menemukan dan memperoleh pengalaman. LC 5E juga memfasilitasi proses pembelajaran dan memberikan kesempatan untuk belajar secara bermakna.

Tahap-tahap yang terdapat pada LC 5E, yaitu sebagai berikut: (1) Tahap engagement, bertujuan mempersiapkan diri dengan cara menggali minat dan rasa ingin tahu; (2) Tahap exploration, kesempatan untuk bekerja sama dalam kelompok-kelompok kecil agar terjadi tukar pikiran; (3) Tahap explanation, mendorong untuk menjelaskan ide yang telah didapat, lalu diwujudkan dalam presentasi kelompok; (4) Tahap elaboration, mengaplikasikan ide serta gagasannya ke dalam menyelesaikan latihan soal; (5) Tahap evaluation, dilakukan evaluasi dengan mengoreksi hasil pekerjaan dan menyimpulkan materi yang telah diberikan (Bybee et al., 2006; Hanuscin \& Lee, 2008).

Peneliti berpendapat bahwa LC 5E tidak akan efektif apabila berdiri sendiri, diperlukan alat bantu yang canggih sebagai "rekan intelektual" untuk mahasiswa. Smaldino, et all (2008) menjelaskan bahwa teknologi dapat menjadi "rekan intelektual" karena teknologi melibatkan dan mendukung siswa dalam pembelajaran. Teknologi merupakan lingkungan yang melibatkan siswa untuk menggunakan strategi belajar kognitif dan kemampuan berpikir kritis. Bahkan di dalam NCTM (2000) tertuang bahwa "Technology is essential in teaching and learning mathematics; it influences the mathematics that is taught and enhances students' learning".

Tidak dapat dipungkiri bahwa penggunaan teknologi memberikan pengaruh yang signifikan dalam proses pembelajaran. Peserta didik dapat belajar secara kolaboratif dan konstruktif melalui interaksi sosial dan eksplorasi diri (Shadaan \& Leong, 2013). Beberapa studi telah melaporkan kefektifan belajar serta juga peningkatan motivasi belajar dengan bantuan software di dalam kelas (Dogan \& İçel, 2011; Meng \& Idris, 2012; Meng \& Sam, 
2013; Abdullah \& Zakaria, 2013, 2013; Carnia dkk, 2014; Pitriani, 2017a; Pitriani, 2017b).

GeoGebra merupakan software yang menggabungkan geometri, aljabar, dan kalkulus. Software ini merupakan software interaktif, sehingga pengguna dapat membuat titik, vektor, garis, ruas garis, polygon dan sebagainya sesuai keperluan. Software ini juga dapat menyajikan koordinat secara langsung sehingga memudahkan pengguna dalam menentukan titik koordinat yang dibutuhkan. Software ini juga dapat menyajikan turunan dan integral suatu fungsi. Aplikasi ini juga cukup ringan, yaitu $41 \mathrm{~kb}$. Aplikasi ini dapat di unduh secara gratis pada http://www.geogebra.org/ (Judith, 2013).

LC 5E berbantuan software Geogebra merupakan pembelajaran berbasis konstruktivisme memberikan kesempatan kepada mahasiswa untuk mengeksplorasi ide-ide matematika melalui GeoGebra sebagai alat bantu. Atmosfir pembelajaran seperti ini sangat memungkinkan untuk mahasiswa meningkatkan prestasi dan kemandirian belajar. Prestasi dan kemandirian belajar yang baik merupakan unsur yang sangat penting untuk dimiliki oleh mahasiswa calon guru.

\section{METODE}

Penelitian ini merupakan penelitian tindakan kelas terdiri atas dua siklus. Penelitian ini dilaksanakan di Jurusan Pendidikan Matematika FKIP Universitas Tamansiswa Palembang, selama bulan September 2017 - Januari 2018 (semester ganjil pada tahun akademik 2017/2018). Subjek penelitian ini adalah mahasiswa Program Studi Pendidikan Matematika yang sedang mengambil mata kuliah Geometri Transformasi. Target subjek penelitian ini berjumlah 15 mahasiswa. Prosedur penelitian yang dilakukan mengacu pada rancangan penelitian yang dikemukakan oleh Kemmis dan Mc.Taggart (Sukmadinata, 2007; Tampubolon, 2014) terdiri atas tiga tahap, yaitu tahap perencanaan, tahap pelaksanaan (tindakan dan observasi), dan tahap refleksi.

Penelitian tindakan kelas yang dilakukan terdiri atas dua siklus. Untuk memperoleh data penelitian digunakan dua perangkat pembelajaran, yaitu rencana perkuliahan dan handout ajar. Instrumen penelitian yang digunakan terdiri atas lembar observasi kegiatan pembelajaran, lembar penilaian presentasi mahasiswa, angket kemandirian belajar mahasiswa, dan tes prestasi belajar.

Data yang diperoleh dianalisis secara kuantitatif dan kualitatif. Teknik kualitatif digunakan untuk menentukan keterlaksanaan rencana perkuliahan dan rencana tindakan, mendeskripsikan aktivitas mahasiswa dan dosen dalam kegiatan pembelajaran, kemampuan mahasiswa berdiskusi dan mempresentasikan tugas, serta hambatan-hambatan yang muncul dalam pelaksanaan pembelajaran. Teknik kuantitatif digunakan untuk mendeskripsikan prestasi belajar mahasiswa, dan untuk mengetahui apakah implementasi pembelajaran dapat meningkatkan kemandirian belajar mahasiswa. Untuk mendeskripsikan implementasi LC 5E.

Untuk mendeskripsikan prestasi belajar mahasiswa akan ditinjau dari ketuntasan belajarnya. Seorang mahasiswa dikatakan tuntas belajar jika memperoleh nilai lebih dari atau sama dengan B (atau skor 75 dalam rentang 
penilaian 0 - 100). Selanjutnya suatu kelas dikatakan tuntas secara klasikal, jika terdapat paling sedikit $75 \%$ mahasiswa telah tuntas belajar secara individual.

Untuk mendeskripsikan kemandirian belajar mahasiswa setelah mengikuti kegiatan pembelajaran, digunakan hasil angket yang diberikan kepada mahasiswa setelah berakhirnya kegiatan perkuliahan. Hasil angket tersebut dianalisis dengan cara sebagai berikut. Mahasiswa dikatakan telah memiliki kemandirian belajar yang baik bila jumlah rata-rata persentase mahasiswa yang memilih kategori Sangat Setuju dan Setuju lebih besar daripada jumlah rata-rata persentase mahasiswa yang memilih kategori Tidak Setuju, Sangat Tidak Setuju.

\section{HASIL DAN PEMBAHASAN}

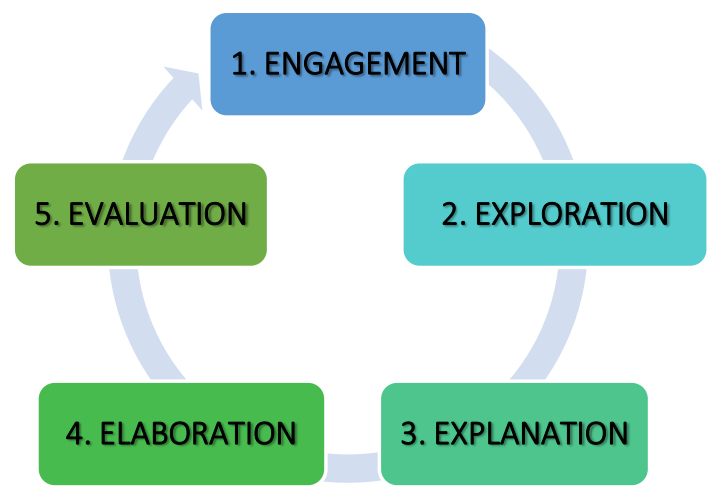

Gambar 1. Tahapan LC 5E

LC 5E terdiri atas lima tahap yaitu (a) pembangkit minat (engagement), (b) eksplorasi (exploration), (c) penjelasan (explanation), (d) elaborasi (elaboration), dan (e) evaluasi (evaluation) (Hanuscin \& Lee, 2008; Bybee et al., 2006; Madu \& Amaechi, 2012).

Penggunaan GeoGebra sebagai alat bantu terlaksana pada tahap kedua yaitu, ekplorasi. Berikut adalah contoh eksplorasi mahasiswa terhadap materi refleksi dengan menggunakan GeoGebra. Mahasiswa menggunakan software sebagai bentuk konfirmasi terhadap konjektur pencerminan segitiga $\mathrm{ABC}$.

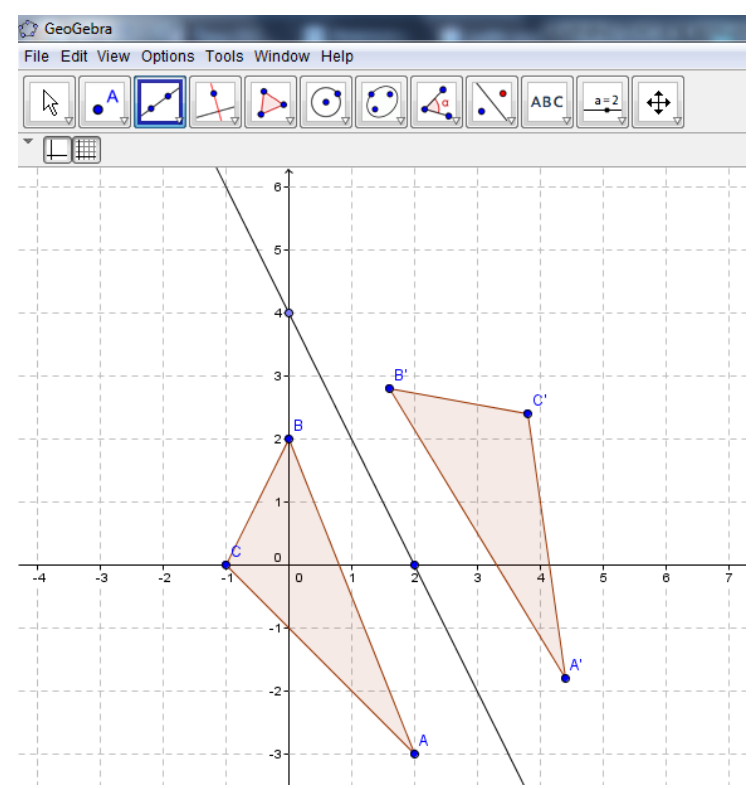

Gambar 2. Contoh Penggunaan GeoGebra

\section{Prestasi Belajar Mahasiswa pada Perkuliahan Geometri Transformasi} Prestasi akhir mahasiswa ditentukan berdasarkan kesepakatan dengan mahasiswa pada awal perkuliahan, yaitu ditentukan berdasarkan nilai tugas dan presentasi, nilai siklus I dan II, dan nilai UAS. Hasil siklus I terdapat 9 mahasiswa dari 15 mahasiswa $(60,00 \%)$ yang mendapatkan nilai 75 ke atas. Hasil siklus II terdapat 13 mahasiswa dari 15 mahasiswa $(86,67 \%)$ yang mendapatkan nilai $75 \mathrm{ke}$ atas.

Tabel 1. Deskrpsi Prestasi Belajar

\begin{tabular}{ccc}
\hline Nilai & \multicolumn{2}{c}{ Jumlah Mahasiswa } \\
Siklus I & Siklus II \\
A & 3 & 4 \\
B & 8 & 10 \\
C & 4 & 1 \\
D & 0 & 0 \\
\hline
\end{tabular}

Ketuntasan belajar yang telah dicapai dikarenakan aktivitas mahasiswa dalam pembelajaran menggunakan LC 
5E. Mahasiswa mengembangkan minat dan ingin rasa tahu terhadap topik di awal pembelajaran. Kemudian, mahasiswa mengeksporasi dengan mencoba, mencatat, mengamati, dan mengembangkan ide-ide baru. Setelah itu, mahasiswa diberikan kesempatan untuk menjelaskan konsep yang ditemukan dengan memberikan pembuktian. Untuk melatih keterampilan dalam menerapkan konsep, mahasiswa menggunakannya dalam situasi baru. Mahasiswa juga melakukan evaluasi terhadap diri sendiri dan menganalisis kekurangan dan kelebihan dalam kegiatan pembelajaran (Hanuscin \& Lee, 2008). Dengan demikian, pembelajaran yang dilaksanakan adalah pembelajaran yang bermakna.

Dalam teori meaningful learning Ausubel (Ratna, 2011), siswa akan memahami suatu konsep jika mahasiswa belajar secara bermakna. Belajar bermakna adalah proses mengaitkan informasi baru dengan konsep-konsep yang relevan dan terdapat dalam kognitif seseorang. Pemahaman siswa akan meningkat jika mahasiswa belajar dengan mengaitkan informasi baru dengan konsep-konsep yang relevan seperti dalam LC 5E. Oleh karena itu, peningkatan prestasi belajar mahasiswa yang ditimbulkan adalah hal yang sangat mungkin.

\section{Kemandirian Belajar Mahasiswa}

Kemandirian belajar tumbuh terindikasi dari meningkatnya keyakinan diri, mahasiswa mampu menggunakan strategi belajar secara mandiri, meningkatnya aktivitas mahasiswa dalam pembelajaran, dan tumbuhnya motivasi ke arah yang lebih baik dalam diri mahasiswa (Mynard \& Sorflaten, 2003; Sumarmo, 2004).

Tabel 2. Deskripsi Kemandirian Belajar

\begin{tabular}{llllll}
\hline \multirow{2}{*}{ No. } & Indikator* & \multicolumn{3}{c}{ Dalam Persen (\%) } \\
& & SS & S & TS & STS \\
2 & Inisiatif Belajar & 13,3 & 66,7 & 13,3 & 6,7 \\
3 & Mendiagnosa Kebutuhan Belajar & 20,0 & 53,3 & 20,0 & 6,7 \\
4 & Menetapkan Target/Tujuan Belajar & 6,7 & 53,3 & 26,7 & 13,3 \\
5 & Memonitor, Mengatur dan Mengontrol & 20,0 & 53,3 & 13,3 & 13,3 \\
6 & Memandang Kesulitan Sebagai Tantangan & 6,7 & 60,0 & 20,0 & 13,3 \\
7 & Memanfaatkan dan Mencari Sumber yang Relevan & 20,0 & 46,7 & 20,0 & 13,3 \\
8 & Memilih dan Menerapkan Strategi Belajar & 13,3 & 66,7 & 13,3 & 6,7 \\
9 & Self Eficacy (Konsep Diri) & 26,7 & 60,0 & 13,3 & 0 \\
Rata-rata & 20,0 & $\mathbf{6 6 , 7}$ & 13,3 & 0 \\
\hline
\end{tabular}

* Masing-masing indikator terdiri dari 3 pernyataan positif, sehingga total ada 27 pernyataan.

Berdasarkan Tabel 2. terlihat bahwa respon positif (SS dan S) lebih tinggi dari respon positif. Sehingga dapat disimpulkan kemandirian belajar mahasiswa masuk kategori baik atau positif. Mahasiswa yang memiliki kemandirian belajar yang baik mampu merencanakan dan berinisiatif dalam pembelajaran. Selain itu, mahasiswa mampu berpikir kritis dan logis serta open minded (Sukarno, 1999).

\section{SIMPULAN DAN SARAN}

Rata-rata prestasi belajar mahasiswa meningkat menjadi 58,56 $(60,00 \%)$ pada siklus I dan 81.44 $(86,67 \%)$ pada siklus II. Mahasiswa memperlihatkan kemandirian belajar positif. Mahasiswa antusias mengikuti pembelajaran. LC 5E dapat diimplementasikan pada perkuliahan sebagai suatu alternatif dalam proses 
pembelajaran berbagai mata kuliah. Pembelajaran ini dapat meningkatkan prestasi dan kemandirian belajar mahasiswa. Mahasiswa dilatih untuk mampu memahami materi secara autodidak/mandiri. Proses pembelajaran ini mampu menumbuhkan rasa ingin tahu, daya diskusi, dan melatih mahasiswa untuk mengemukakan konsep di dalam kelompok. Peneliti lain disarankan untuk menggunakan software lain.

\section{DAFTAR PUSTAKA}

Abdullah, A. H., \& Zakaria, E. (2013). The effects of van hiele's phase-based instruction using the geometer's sketchpad (GSP) on students' levels of geometric thinking. Research Journal of Applied Sciences, Engineering and Technology, 5(5), 1652-1660.

Bybee, R. W., Taylor, J. A., Gardner, A., Van Scotter, P., Powell, J. C., Westbrook, A., \& Landes, N. (2006). The BSCS 5E instructional model: Origins and effectiveness. Colorado Springs, Co: BSCS, 5, 88-98.

Dogan, M., \& İçel, R. (2011). The role of dynamic geometry software in the process of learning: GeoGebra example about triangles. Journal of Human Sciences, 8(1), 1441-1458.

Hanuscin, D. L., \& Lee, M. H. (2008). Using the learning cycle as a model for teaching the learning cycle to preservice elementary teachers. Journal of Elementary Science Education, 20(2), 51.

Judith, \& M. H. (2013). Introduction to GeoGebra Version 4.4.

Lorsbach, A. W. (2002). The learning cycle as a tool for planning science instruction.

Madu, B. C., \& Amaechi, C. C. (2012). Effect of Five-Step Learning Cycle Model on Students' Understanding of Concepts Related to Elasticity.
Journal of Education and Practice, 3(9), 173-181.

Meng, C. C., \& Idris, N. (2012). Enhancing students' geometric thinking and achievement in solid geometry. Journal of Mathematics Education, 5(1), 15-33.

Meng, C. C., \& Sam, L. C. (2013). Enhancing primary pupils' geometric thinking through phasebased instruction using the Geometer's Sketchpad. Asia Pacific Journal of Educators and Education, $28,33-51$.

Mynard, J., \& Sorflaten, R. (2003). Independent learning in your classroom. Retrieved April, 4, 2004.

NCTM. (2000). Principles and standards for school mathematics (Vols. 1-1). National Council of Teachers of.

Pitriani, P. (2017a). Pengembangan LKS berbasis PBL berbantuan Cabri 3D Materi Dimensi Tiga Kelas X SMA. FIBONACCI: Jurnal Pendidikan Matematika Dan Matematika, 3(1), 1-10.

Pitriani, P. (2017b). Problem Based Learning berbantuan Cabri 3D untuk Meningkatkan Habit OF Thinking Flexibly Siswa SMA. Nabla Dewantara: Jurnal Pendidikan Matematika, 1(2), 13-25.

Ratna, W. D. (2011). Teori-teori belajar dan pembelajaran. Bandung: Erlangga.

Shadaan, P., \& Leong, K. E. (2013). Effectiveness of Using GeoGebra on Students' Understanding in Learning Circles. Malaysian Online Journal of Educational Technology, 1(4), 1-11.

Smaldino, S. E., Lowther, D. L., Russell, J. D., \& Mims, C. (2008). Instructional technology and media for learning.

Sukarno, A. (1999). Ciri-ciri Kemandirian Belajar. Jakarta: Kencana Prenada Media. 
Desimal, 1 (2), 2018 - 235

Pitriani

Sukmadinata, N. S. (2007). Metode penelitian. Bandung: PT Remaja Rosda Karya.

Sumarmo, U. (2004). Kemandirian belajar: apa, mengapa, dan bagaimana dikembangkan pada peserta didik. In Makalah pada Seminar Tingkat Nasional. FPMIPA UNY Yogyakarta Tanggal (Vol. 8).

Tampubolon, S. (2014). Penelitian tindakan kelas sebagai pengembangan profesi pendidik dan keilmuan. Jakarta: Erlangga. 